\title{
TRANSFORMATIONS OF LAND AMELIORATION SYSTEMS IN THE CATCHMENT OF THE RÓW WYSKOC RIVER IN THE CONTEXT OF THEIR USE TO COUNTERACT THE EFFECTS OF DROUGHT
}

\author{
Paweł Kozaczyk ${ }^{11}$ \\ 1 University of Life Sciences in Poznan, Wojska Polskiego 28, 60-637 Poznań, Poland, e-mail: kozpawel@ \\ up.poznan.pl
}

Received: 2017.07.10

Accepted: 2017.09.05

Published: 2017.11.01

\begin{abstract}
The regulation of water relations is an important environmental role of permanent greeneries . The valleys used as permanent grasslands often also function as polders or dry flood-control reservoirs. The land amelioration systems realized in the 1970s and 1980s, for economic reasons do not perform the functions they were planned to. Tjis is because their exploitation has been abandoned and the systems still drain the land in an uncontrolled way, i.e.. without the regulation of water level assumed in the original project and without limitation of excessive outflow and excessive irrigation in post-drought periods. Their presence leads to an excessive drying of the valley and, as a consequence, to the changes in the mode of land use, from mown meadows to arable land. The aim of the study reported in this paper was to evaluate the functioning of the hitherto existing amelioration systems in the context of their possible use for alleviation of the effects of drought. The current state of amelioration ditches in the area of three amelioration systems established in the areas near the villages Racot, Wyskoć and Rogaczewo, in the catchment area of the Rów Wyskoć river, was examined in field study. Moreover, the analysis of cartographic materials in GIS environment was performed. As a result, the digital maps of the amelioration objects were made. The digital maps were compared with the maps from the 1970s and 1980s when the objects were open for operation.
\end{abstract}

Keywords: amelioration systems, river valley, lowland river, drought

\section{INTRODUCTION}

Agriculture is particularly sensitive to water deficiency. Drought reduces the production potential of soils and is responsible for the impediments in agricultural production. The deficiency of water, coming from precipitations and moisture content of soil or the lack of water for irrigation, i.e. the hydrological and hydrogeological drought, is a significant barrier in intensification of agricultural production [Bąk et al.2009, Łabędzki 2006]. The deficit of 1 cubic meter of water translates into a decrease of about 0.086 PLN in the profit in agricultural production [Berbeka, 2011]. The loss in crops depends on the drought duration, the area affected and the season in the vegetation period when it appears (the greatest loss takes place when drought falls in the period of crop growth). Depending on the above-mentioned factors, the loss in crops can reach from $30 \%$ to $80 \%$, which can lead to an increase in food prices [Łabędzki, 2004]. Increasing frequency and intensity of droughts implies the necessity of artificial irrigation, i.e. an increase in the use of water. It is expected that the ensuing problem can be a continuous increase in the uncontrolled intake of underground water for irrigations in agriculture. The necessity of working out the plan for alleviation of the effects of draught follows from the Act of Water Law [Journal of Laws of 2015, art. 88, items $469,1590,1642,2295$, of 2016, item 352]. According to the above-mentioned legal solution, 
the protection against the effects of drought is the responsibility of the central and local government administration authorities. The measures of protection against the effect of drought are defined in the plans of counteraction against the effect of drought (PPSS, abbreviation in Polish) in the catchment areas and in the water regions.

Important regulations in this area are defined in the Act of Law of 18.04. 2002, on the state of natural disaster [Journal of Laws of 2014, items $333,915]$. This law defines the notion of a natural disaster and the role of the central and local administration authorities during such a state.

In the Act of Law of 7.07. 2005, on insurance of crops and farm animals, (Journal of Laws of 2016, item 792), the drought is defined by the loss in agricultural activity caused by a drop of the climatic water balance below the value defined for individual crop species and particular soil types, appearing in sixty days the period from $1^{\text {th }}$ April till $30^{\text {th }}$ September. Moreover, Poland as an EU member is obliged to obey the EU Directives that formulate strategic aims of water management, including the counteraction of the effects of drought. The measures taken within the so-called small retention improve the natural retention capacity of a river catchment, which contributes to increasing the volume of water that can be retained in a natural way in the environment and used for supplying the watercourses during the drought [Mioduszewski, 1996,1997; 2003, EU Commission, 2014].

So far, the small retention measures have permitted the storage of small amounts of water and the measures were realized over a small area. However, according to the numerical modelling, the small retention is particularly useful for water supply to the vegetation in the time of drought. Water relations in the soil can be greatly improved if a proper water management is applied [Arnold et al., 1998, Querner et al., 2012; Mioduszewski et al., 2014]. The increased groundwater table permits increased water intake by plants and thus contributes to increased crops. In other words, the potential ability of drainage ditches for retention of water can be used for the improvement of water balance.

Because of the anthropogenic origin of the meadows and pastures that prevail in the river valleys, they belong to the most threatened types of vegetation. Cessation of mowing or grazing is as damaging as the excessive use of these areas or sometimes even more damaging. It leads to secondary succession and choking with weeds.
Mowing was one of the main factors leading to the formation of meadow plant communities and development of a specific combination of species. Presently, there is a tendency to convert permanent grassland into arable land. In order to curb this process and to protect the grasslands that contribute to biological diversity to a high degree and play an important role in storage water, absorption of carbon dioxide and soil protection, specific regulations have been introduced aimed at maintenance of grasslands. According to these regulations, the areas classified to Natura 2000, the permanent grasslands must not be converted or ploughed, including those on peat and marshy soils that need strict protection in order to meet the bird protection directive [2009/147/WE] and the habitat protection directive [92/43/EWG].

\section{THE METHODS AND RANGE OF STUDY}

The catchment area of the Rów Wyskoć river was outlined on the basis of the Raster Map of Hydrographic Divisions in Poland, (the abbreviation in Polish: MPHP) in the scale of 1:50000 (2010) kindly supplied by the National Water Management Authority (KZGW) The physiographic characterization of the catchment area was made on the basis of the topographic maps in the scale 1:10000 and the Digital Model of the Land (NMT) kindly offered by Main Centre of Geodetic and Cartographic Documentation (CODGiK) The land use structure in the catchment area was determined on the basis of the Corine Land Cover project sponsored by the General Inspectorate of Environmental Protection (GIOŚ) The current state of drainage ditches in three areas near the villages Racot, Wyskoć and Rogaczewo, in the catchment area of the Rów Wyskoć river was carefully examined in the field study. The inventory of all amelioration objects was made and the examination was made of the colored orthophoto maps in the GIS environment. In all the studied areas the land was covered with permanent grassland.

According to the physical-geographical regionalization proposed by Kondracki (2002) this area was within the mesoregion of (Kalisz Upland (318.12) and in a small NE part of Leszno Upland) (318.11) that belong to the Microregion South Wielkopolska. Moreover, other fragments of the catchment area belonged to 


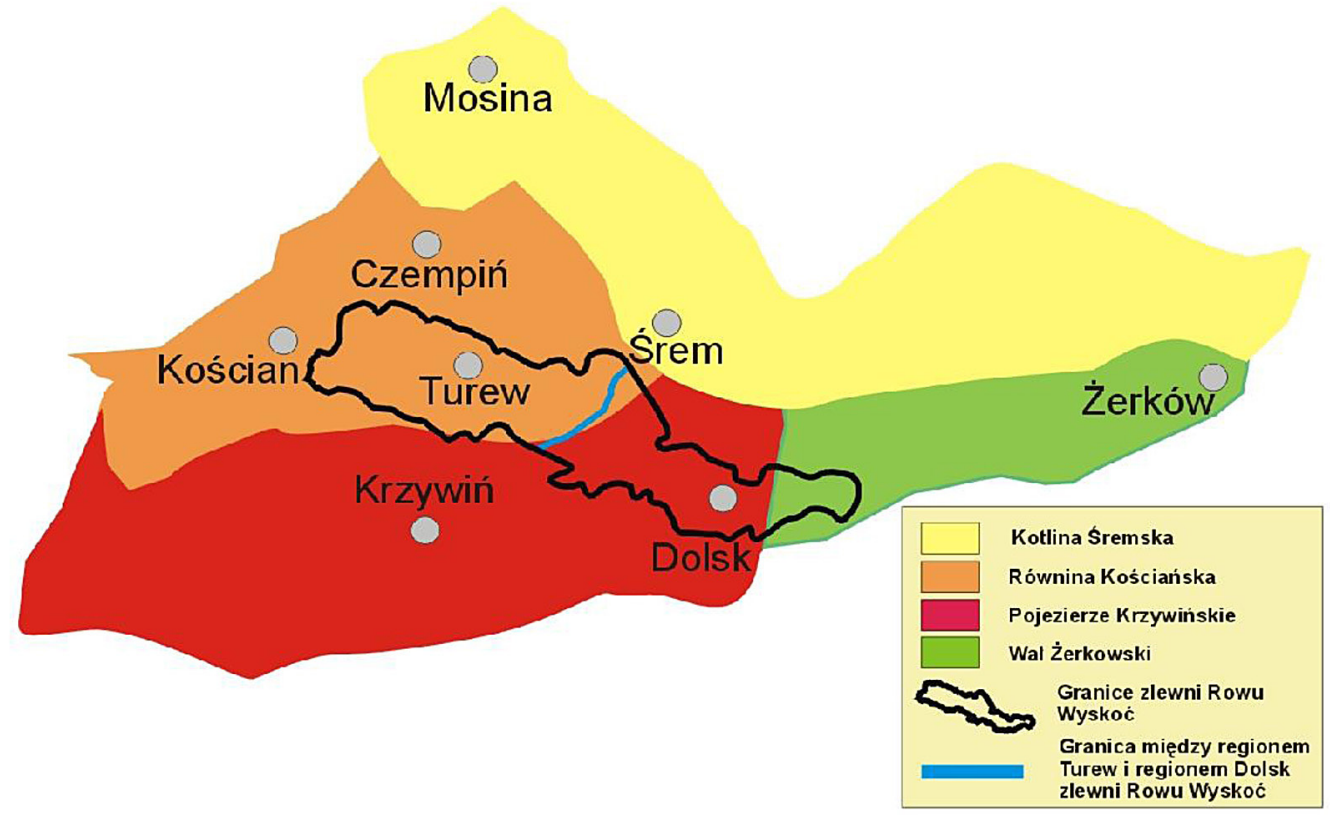

Fig. 1. The Rów Wyskoć catchment area against the background of mesoregions according to the division proposed by Kondracki

the Krzywiń Plain (315.82) and Kościan Plain) (315.83) which are part of the microregion of Wielkopolska Lakeland (Fig.1).

The Kościańska Plain is a typical agricultural region with the predominance of arable lands. In the river valley the dominant studied form of land use were pastures and meadows on silt and gleysol-silt soils. The dominant soil complex of agricultural usefulness is $2 \mathrm{z}$ that occupies $88 \%$ of the catchment area.

The Rów Wyskoć river is the right tributary of the Kościan Obra Channel with the total length of $36.6 \mathrm{~km}$. The total area of the Channel catch- ment is $174.5 \mathrm{~km}^{2}$ (Fig. 2.). Taking into account significant differences in the structure of land use and geomorphology of the Rów Wyskoć catchment area ,it was divided into two parts: Turew and Dolsk regions. The Turew region (the west part of the catchment area) is predominantly covered by arable land characterized by the lack of water bodies. This region occupying the area of 10,135 ha is entirely in the Kościańska Plain. The Dolsk region of the area of 7395 ha comprises a few lakes.

The Row Wyskoć catchment area belongs to 7 small administrative units (powiaty in Pol-

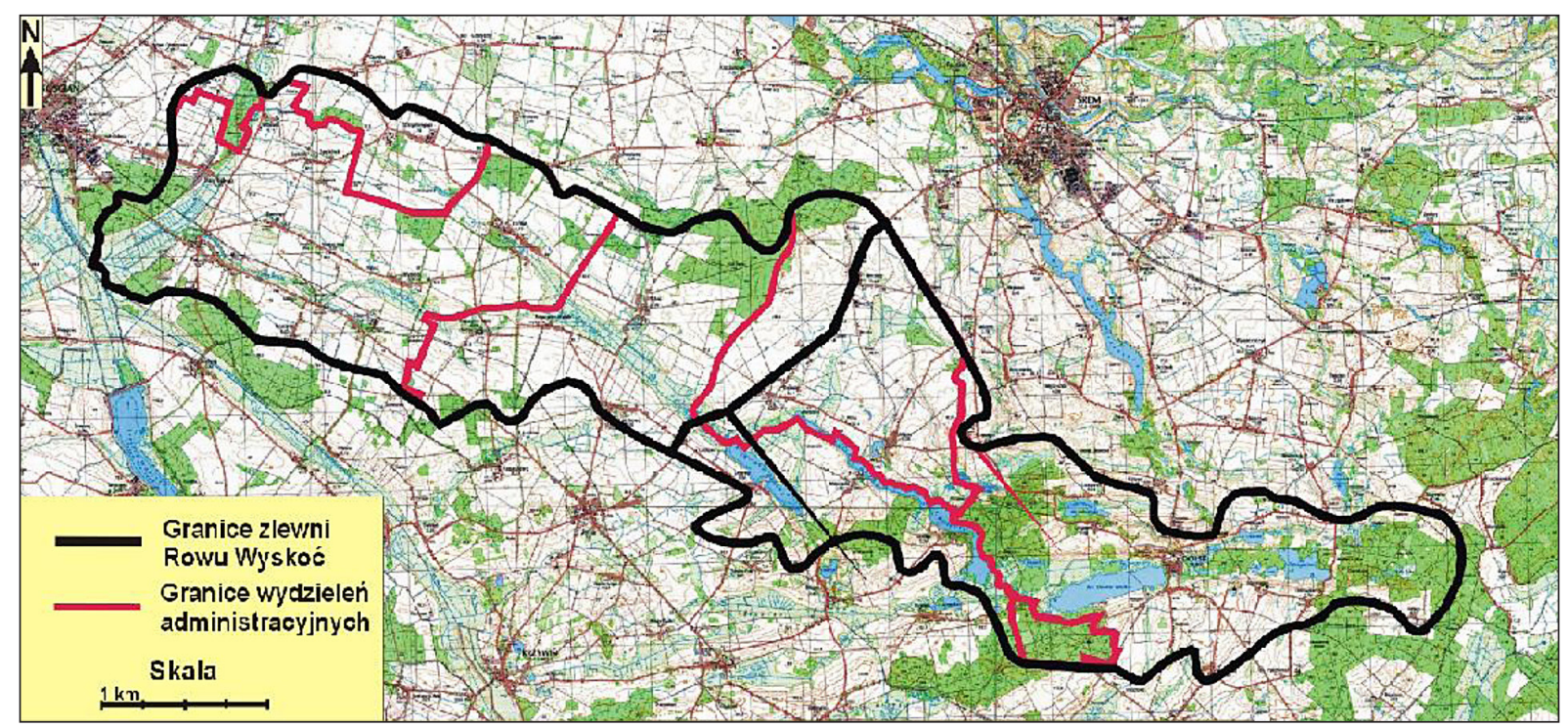

Fig. 2. The Rów Wyskoć catchment area against the background of a topographic map. 


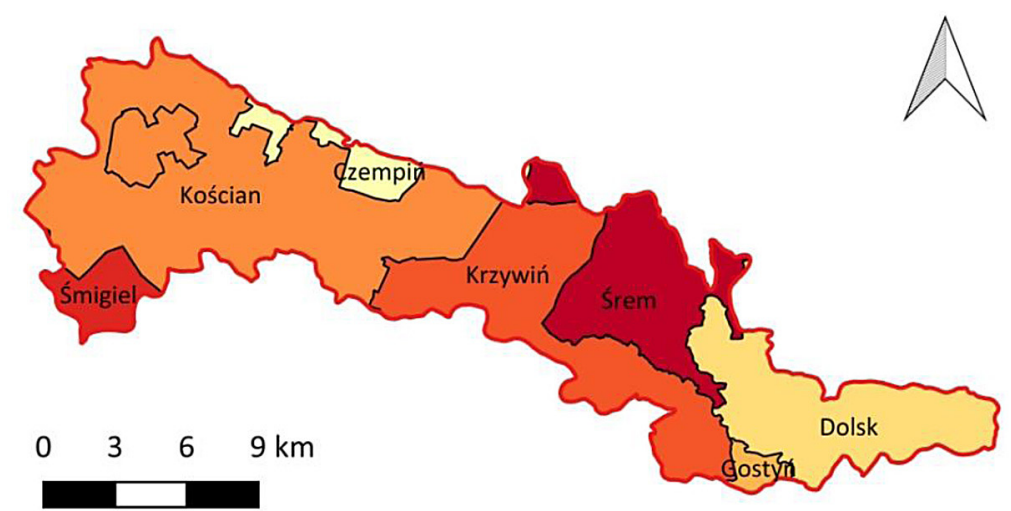

Fig. 3. The basin on the background of administrative division (CODGiK,2017)

ish) of Śmigiel, Kościan, Czempiń, Krzywiń, Śrem, Gostyń and Dolsk (Fig.3.). The channel valley of the Rów Wyskoć along the section between Lake Zbęchy and Kościański Obra Channel is filled with alluvial sediments covered with a $\sim 1 \mathrm{~m}$ thick layer of peat. The top layers of peat, usually of $40-50 \mathrm{~cm}$ thick, have been produced in the murshic process.

The hydrogenic type soils occurring in the area belong to Terric Histosoils, according to FAO 1988 classification. In post-glacial channels, there are also soils formed from organic mud in the vicinity of some small watercourses. They are mainly covered by meadows and occupy a few dozen meter broad band separating the watercourse from the arable land. Deluvial soils, formed of the sand from the slopes of post-glacial channels, can also be found near small watercourses.

In the Rów Wyskoć catchment area, the arable land occupies $74 \%$, while forests cover $14.1 \%$ of the land (Fig. 4.).

\section{RESULTS AND DISCUSSION}

Figures from 5 to 7 present the network of amelioration ditches in particular amelioration systems established in the Rów Wyskoć catchment area. The figures marked with A were drawn on the basis of the topographical map made in 1976, soon after the amelioration systems were opened for exploitation. The number of drainage ditches is by far the highest in Figure 5A, amounting to 159, in Figure 6A there are 79 ditches, and in Figure 7 this number is 124 . The figures marked with $\mathrm{B}$ and $\mathrm{C}$ were drawn on the basis of the orthophoto maps made in the years 1998 and 2013. In 22 years after the establishment of the ditches (1976-1998) their number decreased in Racot to 18, in Wyskoć to 12 and in Rogaczewo to 26, which was a reduction in the ditches number by 88,85 and $79 \%$ with respect to the number in 1976.

Figure 8 presents the total length of drainage ditches in the three areas studied and in the three considered years. In 1976, the amelioration

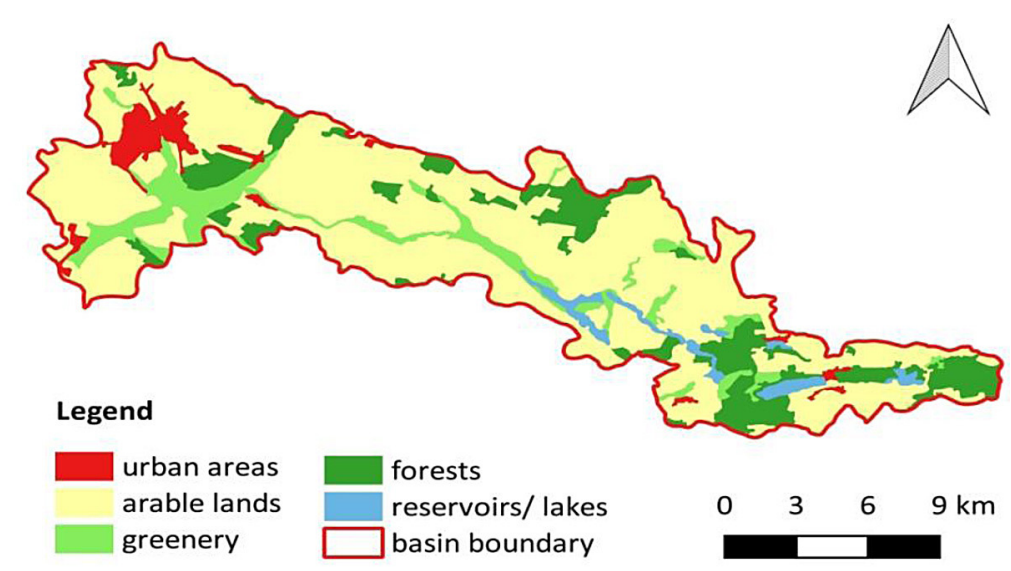

Fig.4. Land use (Corine Land Cover 2006) 


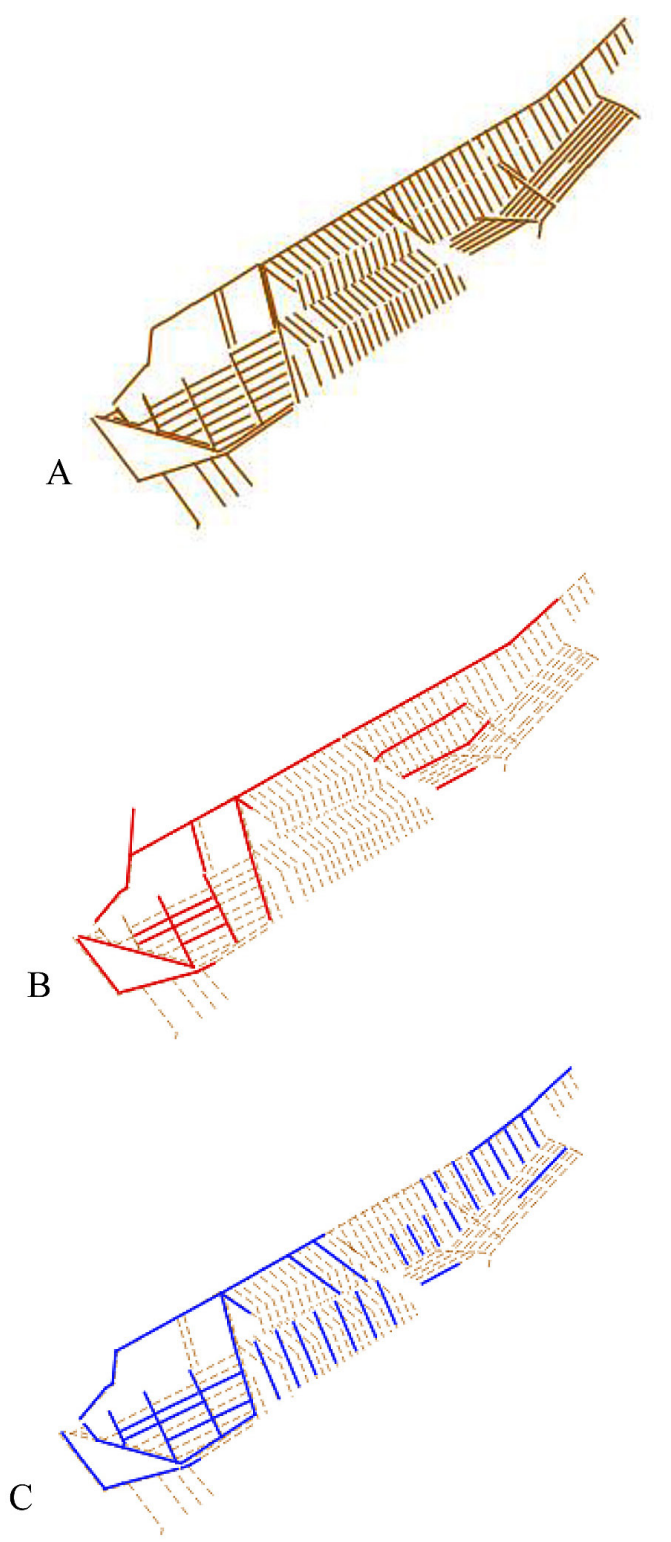

Fig.5. The networks of drainage ditches in 1976 (A), 1998 (B) and 20013 (C) in the amelioration system in Racot village

system in Racot comprised $36 \mathrm{~km}$ of drainage ditches localized over the area of 303 ha, in 1998 the total length of ditches decreased to $8.7 \mathrm{~km}$. After partial modernization and reconstruction of the system in the first decade after 2000 the total length of the ditches increased to $12.5 \mathrm{~km}$. In 1976 there was $0.11 \mathrm{~km}$ of ditches per 1 ha of arable land, in 1998 and 2013 the appropriate ditch lengths per 1 ha were 0.02 and 0.04 , respectively. In Wyskoć and Rogaczewo in 1976 the total length of drainage ditches was $13.5 \mathrm{~km}$ (in the area of $177 \mathrm{ha}$ ) and $27.8 \mathrm{~km}$ (296 ha), while in 1998 it decreased to 3.7 and $3.9 \mathrm{~km}$, respectively. In 2013 the total length of ditches in Wyskoć was

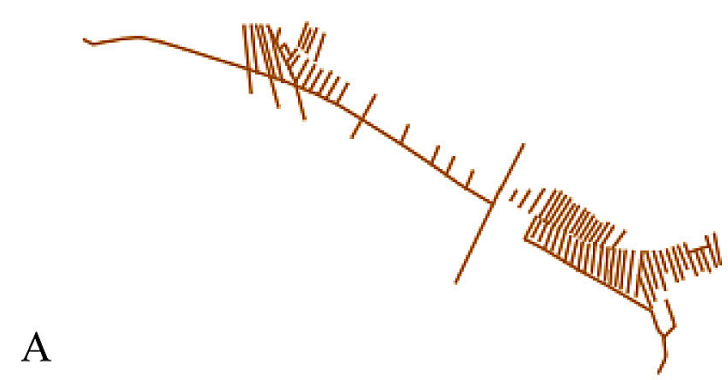

B

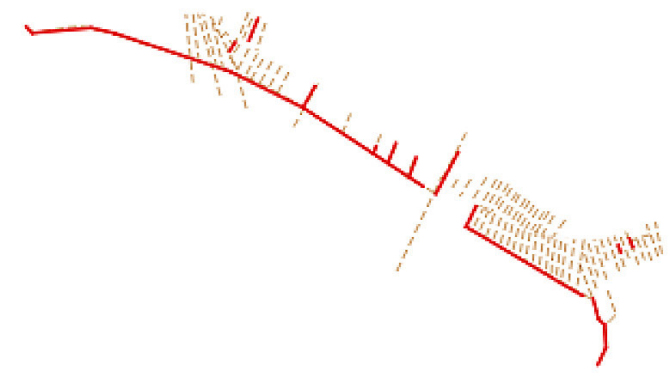

C

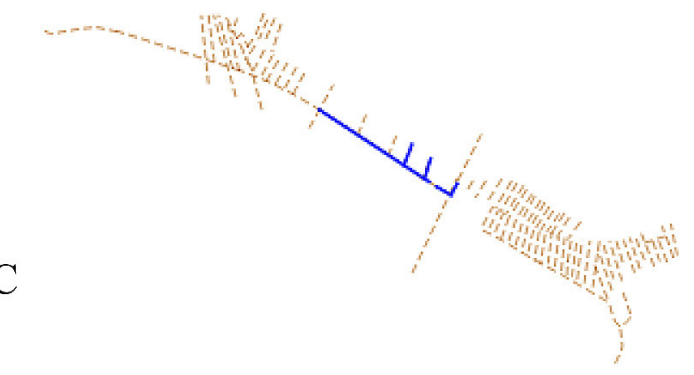

Fig.6. The network of drainage ditches in 1976 (A), 1998 (B) and 2013 (C) in the amelioration system in Wyskoć village

just about $1 \mathrm{~km}$, while in Rogaczewo they were practically nonexistent. In 1976 there was 0.07 $\mathrm{km}$ per 1 ha of arable land in the area covered by the drainage ditches system near Wyskoć, while in 1998 and 2013 the total length of ditches in the same area was 0.02 and 0.005. In 1976 in Rogaczewo there was $0.09 \mathrm{~km}$ per 1 ha of arable land, while in 1998 - only 0.01 .

The maintenance of amelioration devices was the responsibility of the landowners. At the time when they were established, the land belonged to State Farms. The drastic decrease in the length of drainage ditches in the analyzed area was undoubtedly related to the introduc- 
A

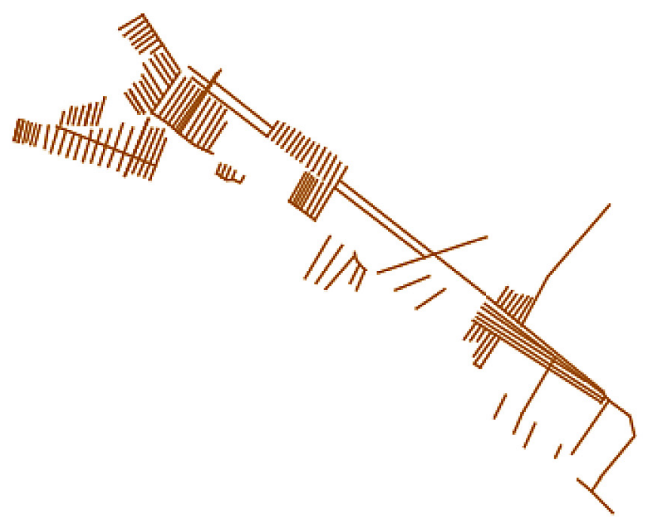

B

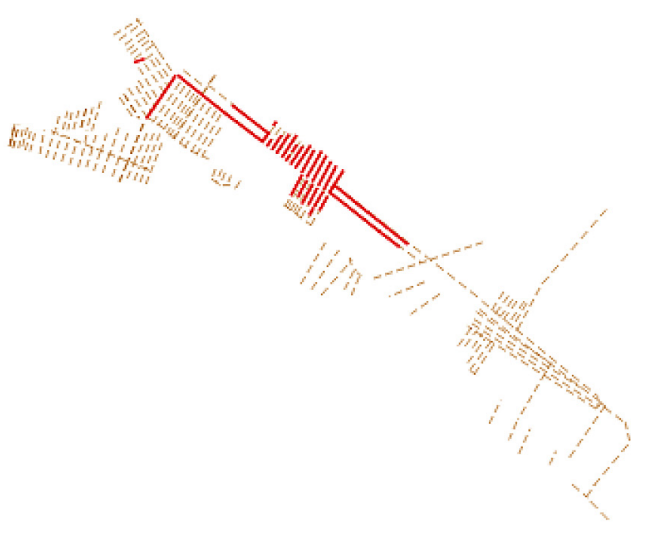

$\mathrm{C}$

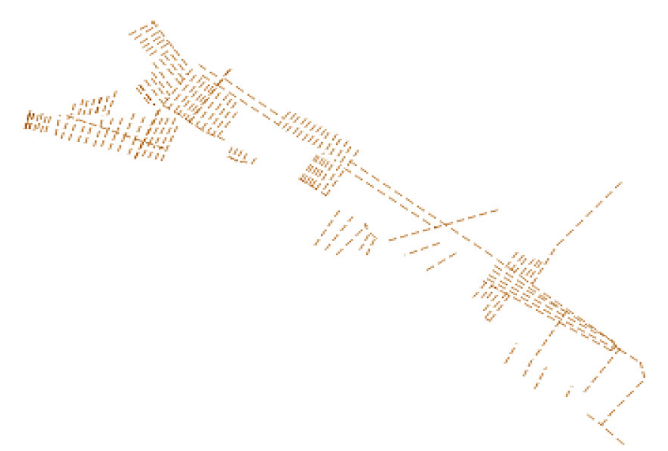

Fig. 7. The network of drainage ditches in 1976 (A), 1998 (B) and 2013 (C) in the amelioration system in Rogaczewo village

tion of market economy and ownership changes as a result of political and economic transformations in the 1990s in Poland. The land owned by the State was leased or sold, which was related to the changes in the structure of crop production in response to market demands and different systemic solutions. Evaluation of the role and impact of the present amelioration systems in river valleys must always take into account the quality of the environment formed and maintained by these systems. The environment of river valleys transformed as a result of amelioration devices usually has developed valuable habitat features. Thus, their change may not be desired or even possible.

In the Rów Wyskoć valley, the exploitation of drainage ditches has been abandoned; however, they still drain the valley in an uncontrolled way, with no predicted regulation of water level, i.e. with no restriction of excessive water outflow or excessive irrigation in post-drought periods. The prolonged uncontrolled drainage can lead to an excessive drying of the valley and local conversion of meadows into arable land by a large number of owners and further degradation of the natural environment. In the Rów Wyskoć valley, the threat may be particularly harmful as it hosts hydrogenic soils. A comprehensive analysis has indicated that the small retention procedures are highly recommended. The recommended procedures include regulation of the outflow from the drainage ditches aimed at increasing of their retention abilities, establishment or re-establishment of small ponds and infield forestation as well as different phyto- and agro-melioration procedures.

On the other hand, the extensively mowed and periodically flooded meadows present in the Rów Wykoć valley make a habitat of exceptionally high natural value. The large diversity of vegetation includes a few rare or protected species. The protection of grasslands, increase and use of agricultural gene resources have been generally approved as a priority in the European agricultural policy, which has been expressed in the Common Agricultural Policy (CAP) for the years 2014-2020, including the Program for Rural Areas Development (PRAD) for the years 2014-2020. These long-term aims will be realized by the climatic activity and intensification of greeneries, advantageous for the climate and natural environment.

\section{CONCLUSIONS}

1. In 1976, the amelioration system in Racot village was comprised of $36 \mathrm{~km}$ of drainage -irrigation ditches, localized in the area of 303 ha. In 1998 , the total length of the ditches decreased to $8.7 \mathrm{~km}$. After partial modernization and reconstruction of the system in the early 2000 s, the length of the ditches increased to $12.5 \mathrm{~km}$. .

2. In the villages Wyskoć and Rogaczewo, the total length of the ditches in 1976 was $13.5 \mathrm{~km}$ (in $177 \mathrm{ha}$ ) and $27.8 \mathrm{~km}$ (in $296 \mathrm{ha}$ ), while in 


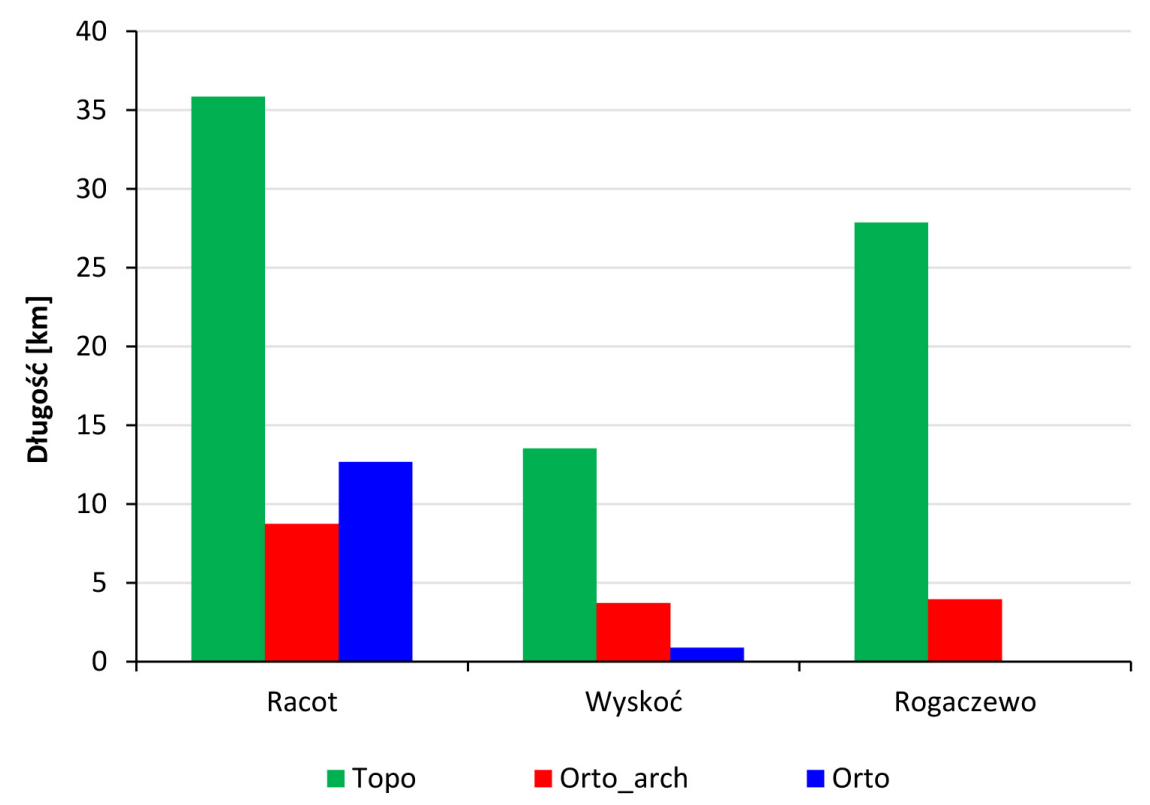

Fig. 8. The length of drainage ditches $(\mathrm{km})$ calculated on the basis of the topographic map from 1976 and orthophoto maps from 1996 and 2013, in particular amelioration systems in the Rów Wyskoć river catchment area

1998 the corresponding lengths were 3.7 and $3.9 \mathrm{~km}$. In 2013, in Wyskoc the total length of the ditches was close to $1 \mathrm{~km}$, while in Rogaczewo the ditches were no longer present.

3. In the Rów Wyskoć valley the exploitation of the amelioration system was ceased, but the ditches still drain the area in the uncontrolled way, i.e. with no predicted regulation of water level. The small retention procedures that include regulation of the outflow from the drainage ditches aimed at increasing of their retention abilities, establishment or re-establishment of small ponds and infield forestation as well as different phyto- and agro-melioration procedures are the recommended solutions.

\section{REFERENCES}

1. Arnold, J.G., Srinivasan, R., Muttiah, R.S. and Williams, J.R. 1998. Large area hydrologic modeling and assessment. Part I: Model development. J. Am. Water Resour. Assoc., 34 (1), 126-134.

2. Bąk B., Łabędzki L. 2009. Monitoring suszy meteorologicznej i rolniczej na Kujawach i w dolinie górnej Noteci oraz jego prezentacja w Internecie. Wiad. Melior. i Łąk., 1, 13-16.

3. Berbeka, K. 2011. Analiza kosztów środowiskowych i zasobowych zgodnie z art. 9 RDW 2000/60/ WE. Gliwice

4. Commission of the EU Communities, 2007. Com- munication from the Commission to the European Parliament and the Council - Addressing the challenge of water scarcity and droughts in the European Union. Summary of the impact Assessment. COM (2007), 414.

5. Kondracki J. 2002. Geografia regionalna Polski. PWN, Warszawa.

6. Łabędzki L. 2004, Problematyka susz w Polsce, Instytut Melioracji i Użytków Zielonych, Wielkopolsko-Pomorski Ośrodek Badawczy w Bydgoszczy, Woda-Środowisko-Obszary Wiejskie: t. 4, z.1 (10), 47-66

7. Łabędzki L. 2006. usze rolnicze - zarys problematyki oraz metody monitorowania i klasyfikacji. Woda a Środowisko Obszary Wiejskie. Rozpr. Nauk. Monogr., 17, 107 pp.

8. Mioduszewski W. 1996. Mała retencja a ochrona zasobów wodnych. Zeszyty Naukowe AR we Wrocławiu.

9. Mioduszewski W. 1997. Formy małej retencji I warunki jej wdrażania. Informacje Naukowe i Techniczne No. 1, 12-18.

10. Mioduszewski W., 2003. Mała retencja. Wydawnictwa IMUiZ.

11. Mioduszewski W., Querner E., Kowalewski Z. 2014. Analysis of the impact of small water retention on water resources in the catchment. Journal of Water and Land Development, 22, 67-78.

12. Querner E.P., Jansen P.C., van der Akker J.J.K., Kwakernaak C. 2012. Analysing water level strategies to reduce soil subsidence in Dutch peat meadows. Journal of Hydrology 446-447, 45-60. 